\title{
Basin-scale variability of microbial methanol uptake in the Atlantic Ocean
}

\author{
Stephanie L. Sargeant ${ }^{1, \text { a }}$, J. Colin Murrell ${ }^{2}$, Philip D. Nightingale ${ }^{1}$, and Joanna L. Dixon ${ }^{1}$ \\ ${ }^{1}$ Plymouth Marine Laboratory, Prospect Place, West Hoe, Plymouth, Devon, PL1 3DH, UK \\ ${ }^{2}$ School of Environmental Science, University of East Anglia, Norwich Research Park, Norwich, NR4 7TJ, UK \\ ${ }^{a}$ now at: Centre for Research in Biosciences, University of the West of England, Frenchay Campus, \\ Coldharbour Lane, Bristol, BS16 1QY, UK
}

Correspondence: Joanna L. Dixon (jod@pml.ac.uk)

Received: 16 January 2018 - Discussion started: 9 February 2018

Revised: 16 July 2018 - Accepted: 4 August 2018 - Published: 28 August 2018

\begin{abstract}
Methanol is a climate-active gas and the most abundant oxygenated volatile organic compound (OVOC) in the atmosphere and seawater. Marine methylotrophs are aerobic bacteria that utilise methanol from seawater as a source of carbon (assimilation) and/or energy (dissimilation). A few spatially limited studies have previously reported methanol oxidation rates in seawater; however, the basin-wide ubiquity of marine microbial methanol utilisation remains unknown. This study uniquely combines seawater ${ }^{14} \mathrm{C}$ labelled methanol tracer studies with 16S rRNA "pyrosequencing" to investigate variability in microbial methanol dissimilation and known methanol-utilising bacteria throughout a meridional transect of the Atlantic Ocean between $47^{\circ} \mathrm{N}$ to $39^{\circ} \mathrm{S}$. Microbial methanol dissimilation varied between 0.05 and $1.68 \mathrm{nmol} \mathrm{L}^{-1} \mathrm{~h}^{-1}$ in the top $200 \mathrm{~m}$ of the Atlantic Ocean and showed significant variability between biogeochemical provinces. The highest rates of methanol dissimilation were found in the northern subtropical gyre (average $0.99 \pm 0.41 \mathrm{nmol} \mathrm{L}^{-1} \mathrm{~h}^{-1}$ ), which were up to 8 times greater than other Atlantic regions. Microbial methanol dissimilation rates displayed a significant inverse correlation with heterotrophic bacterial production (determined using ${ }^{3} \mathrm{H}$-leucine). Despite significant depth stratification of bacterial communities, methanol dissimilation rates showed much greater variability between oceanic provinces compared to depth. There were no significant differences in rates between samples collected under light and dark environmental conditions. The variability in the numbers of SAR11 (16S rRNA gene sequences) were estimated to explain approximately $50 \%$ of the changes in microbial methanol dissimilation
\end{abstract}

rates. We estimate that SAR11 cells in the Atlantic Ocean account for between $0.3 \%$ and $59 \%$ of the rates of methanol dissimilation in Atlantic waters, compared to $<0.01 \%-2.3 \%$ for temperate coastal waters. These results make a substantial contribution to our current knowledge and understanding of the utilisation of methanol by marine microbial communities, but highlight the lack of understanding of in situ methanol production mechanisms.

\section{Introduction}

Methanol is the most abundant oxygenated volatile organic compound (OVOC) in the background troposphere where it acts as a climate-active gas, influencing the oxidative capacity of the atmosphere, concentrations of ozone and hydroxyl radicals (Carpenter et al., 2012). Methanol has been shown to be ubiquitous in waters of the Atlantic Ocean ranging between $<27$ and $361 \mathrm{nM}$ (Williams et al., 2004; Beale et al., 2013; Yang et al., 2013, 2014). Our knowledge of the sources and sinks of methanol is limited and often lacks consensus. For example, recent eddy covariance flux estimates demonstrated a consistent flux of atmospheric methanol into the surface waters of a meridional transect of the Atlantic Ocean (Yang et al., 2013). However, along a similar transect, 12 months earlier, Beale et al. (2013) calculated that the Atlantic Ocean represents an overall source of methanol to the atmosphere $\left(3 \mathrm{Tg} \mathrm{yr}^{-1}\right)$, which was largely attributable to an efflux from the North Atlantic Gyre; where surface concentrations were as high as $361 \mathrm{nM}$. Wet deposition from rain- 
water has also recently been suggested to represent a supply of methanol to the ocean (Felix et al., 2014).

Although in situ marine photochemical production of methanol has previously been found to be insignificant (Dixon et al., 2013), there is thought to be a substantial unidentified biological source of methanol in seawater (Dixon et al., 2011a). Biological production by phytoplankton and during the breakdown of marine algal cells are possible sources (Sieburth and Keller, 1989; Nightingale, 1991; Heikes et al., 2002). Recent laboratory culture experiments suggest that methanol is produced by a wide variety of phytoplankton including cyanobacteria (Prochlorococcus marinus, Synechococcus sp. and Trichodesmium erythraeum) and Eukarya (Emiliania huxleyi, Phaeodactylum tricornutum, Nannochloropsis oculata, and Dunaliella tertiolecta; Mincer and Aicher, 2016; Halsey et al., 2017). The mechanisms of in situ methanol production and their regulation remains largely unknown, although Halsey et al. (2017) reported light-dependent rates of methanol production in cultures of the marine green flagellate Dunaliella tertiolecta (cell size of 10-12 $\mu \mathrm{m}$ ).

Methylotrophic bacteria are capable of utilising onecarbon compounds including methanol as their sole source of energy (methanol dissimilation) and carbon (methanol assimilation). Methylotrophs are widespread in terrestrial and aquatic systems (Kolb, 2009), but research into these bacteria in marine environments is still at an early stage. Traditionally, methylotrophs were thought to utilise methanol dehydrogenase (MDH, encoded by mxaF; McDonald and Murrell, 1997) to metabolise methanol to formaldehyde, with further oxidation to $\mathrm{CO}_{2}$ or incorporation of carbon into biomass (Chistoserdova et al., 2009; Chistoserdova, 2011). However, recent progress in this field has resulted in the discovery of the $x o x F$ gene, encoding an alternative MDH (Wilson et al., 2008) and seemingly present in all known gram-negative methylotrophs to date (Chistoserdova et al., 2009; Chistoserdova, 2011). The presence of methylotrophs in seawater has been confirmed using a range of molecular approaches including functional gene primers, stable isotope probing and metaproteomics (Neufeld et al., 2007, 2008; Dixon et al., 2013; Grob et al., 2015; Taubert et al., 2015). There are also bacterial cells that utilise methanol and other $\mathrm{C}_{1}$ compounds for the production of energy but not biomass, e.g. SAR11 for which Sun et al. (2011) proposed the new term "methylovores", distinct from true methylotrophs which use $\mathrm{C}_{1}$ compounds as sources of carbon and energy.

Limited studies of microbial methanol assimilation in the Atlantic Ocean have previously shown rates up to $0.42 \mathrm{nmol} \mathrm{L}^{-1} \mathrm{~h}^{-1}$ in recently upwelled coastal waters of the Mauritanian upwelling (Dixon et al., 2013). However, open ocean waters of the Atlantic were substantially lower ranging between 0.002 and $0.028 \mathrm{nmol} \mathrm{L}^{-1} \mathrm{~h}^{-1}$ (Dixon et al., 2013). Microbial methanol dissimilation rates are generally up to 1000 -fold higher than rates of assimilation; ranging between 0.70 and $11.2 \mathrm{nmol} \mathrm{L}^{-1} \mathrm{~h}^{-1}$ compared to between $<0.001$ and $0.026 \mathrm{nmol} \mathrm{L}^{-1} \mathrm{~h}^{-1}$, respectively, for coastal waters (Dixon et al., 2011b; Sargeant et al., 2016). Methanol dissimilation rates ranging between 0.08 and $6.1 \mathrm{nmol} \mathrm{L}^{-1} \mathrm{~h}^{-1}$ have also been found in open ocean Atlantic waters (Dixon et al., 2011a). However, despite the ubiquity of methanol in seawater, the spatial extent or quantification of microbial methanol utilisation for energy production on a basin scale has not been previously investigated. Therefore, the objective of this research was to simultaneously characterise the spatial variability in microbial methanol dissimilation rates (at depths to $200 \mathrm{~m}$ ) and in microbial community groups throughout contrasting biogeochemical regions of the Atlantic Ocean. This study represents the first basin-wide approach to investigating methanol as a source of reducing power and energy for microbes.

\section{Materials and methods}

\subsection{Sampling strategy}

Sampling was carried out during an Atlantic Meridional Transect (AMT) voyage (http://www.amt-uk.org, last access: 21 August 2018). The research cruise (JC039, RRS James Cook, 13/10/09-01/12/09) departed from Falmouth, UK $\left(50.15^{\circ} \mathrm{N}, 05.07^{\circ} \mathrm{W}\right)$, and arrived in Punta Arenas, Chile $\left(53.14^{\circ} \mathrm{S}, 70.92^{\circ} \mathrm{W}\right)$. Water samples were collected daily from pre-dawn $(97 \%, 33 \%, 14 \%$ and $1 \%$ photosynthetically active radiation, PAR, equivalent depths and $200 \mathrm{~m}$ ) and solar noon (97\%) conductivity, temperature and depth (CTD) casts. The PAR equivalent depths were 5, 10$31,15-54$ and $38-127 \mathrm{~m}$ for the $97 \%, 33 \%, 14 \%$ and $1 \%$ light levels, respectively, and typically varied with oceanic province. The pre-dawn and solar noon sampling periods were approximately 45-65 nautical miles apart (sampling locations are shown in Fig. 1). The Atlantic Ocean was divided into five oceanic provinces, following the approach of Dixon et al. (2013), according broadly to chlorophyll $a$ concentrations $\left(<0.15 \mathrm{mg} \mathrm{m}^{-3}\right.$ gyre regions, $>0.15 \mathrm{mg} \mathrm{m}^{-3}$ temperate or upwelling regions; Fig. 1) with the northern gyre subdivided into the northern subtropical gyre (NSG) and the northern tropical gyre (NTG). Measurements of the concentration of methanol in seawater (Beale et al., 2013) and of methanol assimilation rates (Dixon et al., 2013) made during this transect have been reported previously.

\subsection{Microbial methanol uptake}

The oxidation of methanol to $\mathrm{CO}_{2}$ (dissimilation) was determined using ${ }^{14} \mathrm{C}$-labelled methanol (American Radiolabeled Chemicals Inc, Saint Louis, MO, USA) seawater incubations as previously described in Dixon et al. (2011b). Seawater samples of $1 \mathrm{~mL}$ were incubated with $\sim 10 \mathrm{nM}$ (final concentration) ${ }^{14} \mathrm{C}$-labelled methanol to measure rates of microbial methanol dissimilation. Seawater methanol concentrations ranged between 48 and $361 \mathrm{nM}$ (Beale et al., 2013), thus 


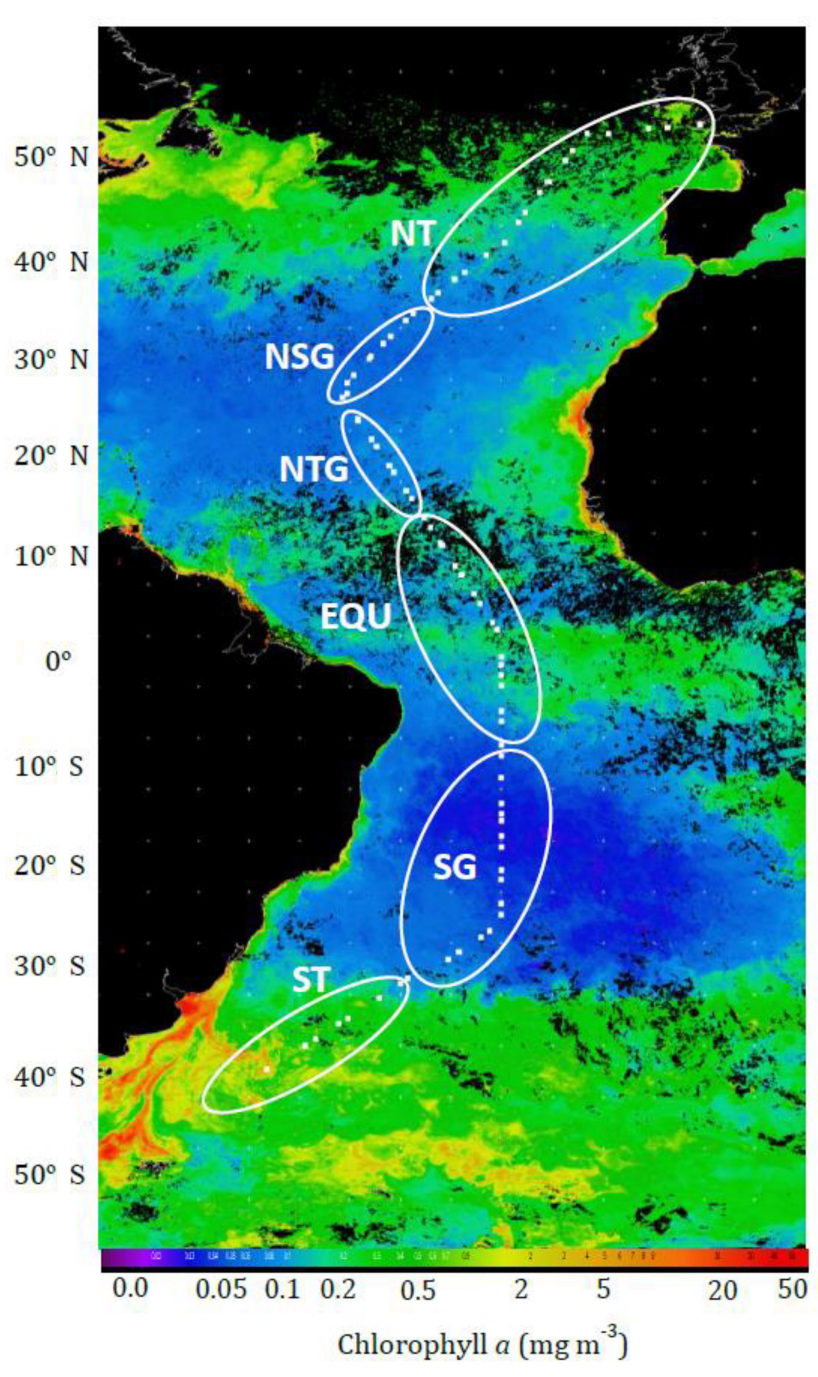

Figure 1. Remotely sensed MODIS-Aqua chlorophyll $a$ composite image of the Atlantic Ocean from November 2009 (image courtesy of NEODAAS). White squares represent sampling points and ovals indicate samples within different oceanic provinces, labelled with province names NT (northern temperate), NSG (northern subtropical gyre), NTG (northern tropical gyre), EQU (equatorial upwelling), SG (southern gyre) and ST (southern temperate).

the radiotracer additions represent $3 \%-21 \%$ of in situ concentrations in Atlantic waters. Incubations were conducted in triplicate, with "killed" controls (5\% trichloroacetic acid, TCA, final concentration), at in situ temperatures and in the dark. Incubation temperatures were determined by the sea surface temperature recorded by the corresponding CTD casts. Sample counts of ${ }^{14} \mathrm{CO}_{2}$, captured in the precipitate as $\mathrm{Sr}^{14} \mathrm{CO}_{3}\left(\mathrm{nCi} \mathrm{mL}{ }^{-1} \mathrm{~h}^{-1}\right.$, where $\mathrm{Ci}$ is the unit Curie, $1 \mathrm{Ci}$ $=3.7 \times 10^{10} \mathrm{~Bq}$ ), were divided by the total ${ }^{14} \mathrm{CH}_{3} \mathrm{OH}$ added to the sample $\left(\mathrm{nCi} \mathrm{mL}^{-1}\right)$ to calculate the apparent rate constants, $k\left(\mathrm{~h}^{-1}\right)$.

The incorporation of methanol carbon into microbial biomass (assimilation) was determined using sample vol- umes of $320 \mathrm{~mL}$ to increase the total sample counts (Dixon et al., 2011b) following procedures outlined in Dixon et al. (2011b, 2013). Filter sample counts were divided by the total ${ }^{14} \mathrm{CH}_{3} \mathrm{OH}$ added to the sample $\left(\mathrm{nCi} \mathrm{mL}^{-1}\right)$ to calculate the apparent rate constants, $k\left(\mathrm{~h}^{-1}\right)$. Methanol uptake rates in $\mathrm{nmol} \mathrm{L}^{-1} \mathrm{~h}^{-1}$ were calculated by dividing the sample counts $\left(\mathrm{nCi} \mathrm{L}^{-1} \mathrm{~h}^{-1}\right)$ by the specific activity of ${ }^{14} \mathrm{C}$-labelled methanol $\left(57.1 \mathrm{Ci} \mathrm{mol}^{-1}\right)$ following the approach of Dixon et al. (2013). Evaluation of control samples suggests that $\leq 0.3 \%$ of the added ${ }^{14} \mathrm{CH}_{3} \mathrm{OH}$ is recovered on the filters and $\leq 2 \%$ in the resultant precipitate for methanol assimilation and dissimilation, respectively.

\subsection{Bacterial leucine incorporation}

Rates of bacterial leucine incorporation were measured using the incorporation of ${ }^{3} \mathrm{H}$-leucine into bacterial protein in seawater samples using the method described by Smith and Azam (1992). A final concentration of $25 \mathrm{nM}(6.8 \mu \mathrm{L})$ of ${ }^{3} \mathrm{H}$-leucine (calculated using the specific activity of 161 $\mathrm{Ci} \mathrm{mmol}^{-1}$, concentrations $1 \mathrm{mCi} \mathrm{mL}^{-1}$, American Radiolabeled Chemicals Inc, Saint Louis, MO, USA) was incubated with $1.7 \mathrm{~mL}$ seawater samples. Incubations were conducted in triplicate with "killed" controls (5\% TCA, final concentrations), at in situ temperature and in the dark.

\subsection{Bacterial community composition}

Seawater samples of approximately 20 litres were collected for bacterial DNA analysis from $97 \%, 33 \%, 1 \%$ and $<1 \%$ (200 m) PAR equivalent depths during pre-dawn CTD casts only. Samples were filtered through $0.22 \mu \mathrm{m}$ Sterivex polyethersulfone filters (Millipore, Watford, UK) using a peristaltic pump. Filters were incubated with $1.6 \mathrm{~mL}$ of RNA Later (Life Technologies, to preserve samples during shipment) overnight at $4{ }^{\circ} \mathrm{C}$, after which the RNA Later was removed. Filters were stored immediately at $-80^{\circ} \mathrm{C}$ before being shipped back to the UK on dry ice and subsequently stored at $-20^{\circ} \mathrm{C}$.

Bacterial DNA was extracted from filters using a modified phenol: chloroform : isoamyl alcohol extraction method as previously described in Neufeld et al. (2007). Extracted DNA was cleaned using Amicon ultra- 0.5 centrifugal filter devices (Millipore) to remove any RNA Later residue. The 16S rRNA gene primers 341F (Muyzer et al., 1993) and 907R (Muyzer et al., 1998) were used for PCR amplification ( 32 cycles) with an annealing temperature of $55^{\circ} \mathrm{C}$. Purification of PCR products from agarose gels was conducted using the QIAquick gel extraction kit (Qiagen, Crawley, UK) before being sent to Molecular Research LP (MR DNA, http://www.mrdnalab.com, last access: 21 August 2018) for 454 pyrosequencing using the GS-FLX platform.

The 16S rRNA gene sequences were depleted of barcodes and primers, and then sequences less than $200 \mathrm{bp}$, with ambiguous bases or with homopolymer runs exceeding $6 \mathrm{bp}$, 
were removed. Sequences were de-noised and chimeras removed. After the removal of singleton sequences, operational taxonomic units (OTUs) were defined at $97 \% 16 \mathrm{~S}$ rRNA gene identity using Quantitative Insights Into Microbial Ecology (QIIME, http://qiime.org, last access: 21 Auust 2018; Caporaso et al., 2010). The OTUs were assigned taxonomically using BLASTn (Basic Local Alignment Search Tool, NCBI) against the Silva database (http: //www.arb-silva.de, last access: 21 August 2018). Sequences were randomly resampled to the lowest number of sequences per sample (386 sequences per DNA sample) to standardise the sequencing effort.

\section{Results}

\subsection{Microbial methanol dissimilation}

\subsubsection{Surface}

Pre-dawn surface rates of microbial methanol dissimilation ranged between 0.05 and $1.49 \mathrm{nmol} \mathrm{L}^{-1} \mathrm{~h}^{-1}$ throughout the transect of the Atlantic Ocean (Fig. 2a). Maximum variability in surface rates of methanol dissimilation (average of $0.96 \pm 0.45 \mathrm{nmol} \mathrm{L}^{-1} \mathrm{~h}^{-1}, n=10$ ) were observed north of $25^{\circ} \mathrm{N}$ in the northern temperate (NT) and NSG regions. At the southern limit of the NSG, rates of methanol dissimilation decreased sharply from 1.48 to $0.34 \mathrm{nmol} \mathrm{L}^{-1} \mathrm{~h}^{-1}$. Generally, surface rates continued to decrease in a southward direction throughout the NTG and EQU regions, reaching a minimum of $0.05 \mathrm{nmol} \mathrm{L}^{-1} \mathrm{~h}^{-1}$ in equatorial upwelling waters. Interestingly, surface rates started to gradually increase to $0.39 \mathrm{nmol} \mathrm{L}^{-1} \mathrm{~h}^{-1}$ in waters of the oligotrophic SG, before declining to $0.18 \mathrm{nmol} \mathrm{L}^{-1} \mathrm{~h}^{-1}$ in the ST area. Methanol dissimilation rates determined at pre-dawn (dark) generally exhibited a similar latitudinal pattern to those from solar noon (light). Rates south of $25^{\circ} \mathrm{N}$ (NTG, EQU, SG, ST) showed a significant, almost 1:1 relationship, between light (solar noon, $y$ ) and dark (pre-dawn, $x$ ) in situ sampling conditions $(y=1.06 x, r=0.6240, n=13, P<0.05)$, with most variability between results from light versus dark sampling occurring north of $25^{\circ} \mathrm{N}$ in the NT and NSG provinces. This is most likely a reflection of these waters exhibiting the greatest spatial variability, as the pre-dawn and midday stations were typically 55 nautical miles apart.

\subsubsection{Depth distributions}

The average rates of methanol dissimilation with depth are shown in Fig. 3a for each oceanic province. Rates varied between 0.05 and $1.68 \mathrm{nmol} \mathrm{L}^{-1} \mathrm{~h}^{-1}$, but showed no consistent statistically significant trend with depth. However, clear differences were observed in microbial methanol dissimilation in the top $200 \mathrm{~m}$ between contrasting provinces in the Atlantic Ocean; where $\mathrm{NSG} \geq \mathrm{NT}>\mathrm{SG} \approx \mathrm{ST} \geq \mathrm{NTG}>\mathrm{EQU}$. The highest rates of methanol dissimilation in the top $200 \mathrm{~m}$
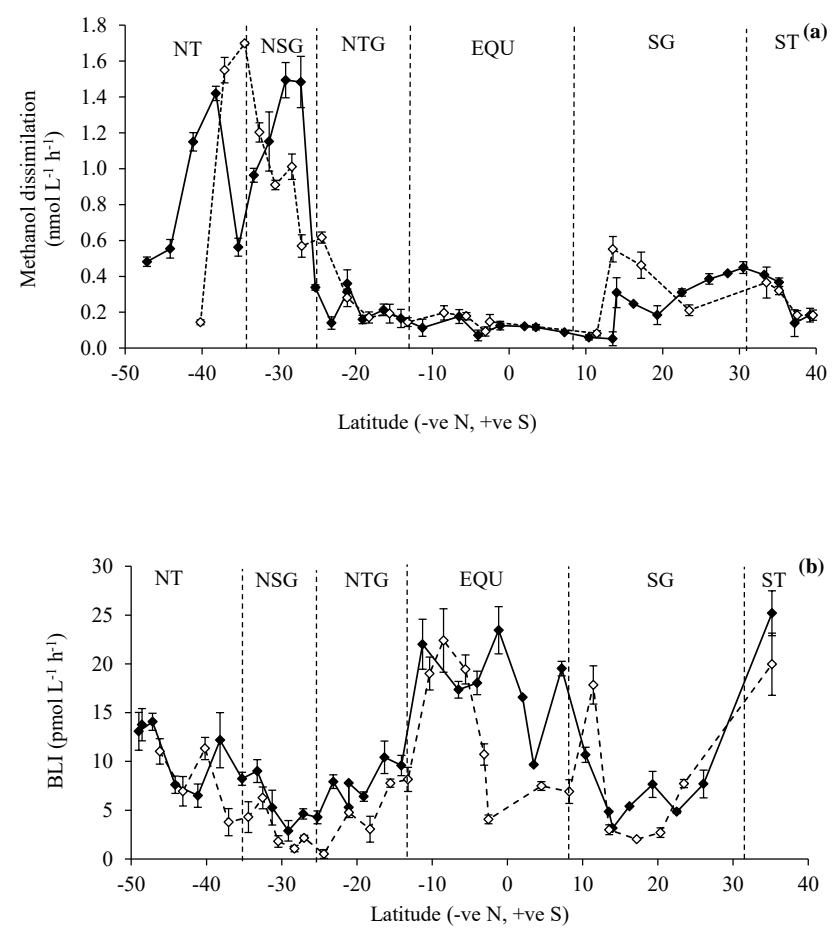

Figure 2. Variability in (a) microbial methanol dissimilation rates (using the specific activity of ${ }^{14} \mathrm{CH}_{3} \mathrm{OH}$ ) and (b) bacterial leucine incorporation (BLI), in surface waters of the Atlantic Ocean. Rates were determined from pre-dawn $(\diamond$, solid line) and solar noon $(\diamond$, dashed line) CTD casts. Error bars represent \pm 1 SD of triplicate samples and dashed vertical lines indicate Atlantic province boundaries.

were observed in the most northern latitudes $(0.22-1.50$ and $0.15-1.68 \mathrm{nmol} \mathrm{L}^{-1} \mathrm{~h}^{-1}$ for NT and NSG, respectively), consistent with surface trends (Fig. 2a). A strong decrease was observed between the NSG $\left(0.99 \pm 0.41 \mathrm{nmol} \mathrm{L}^{-1} \mathrm{~h}^{-1}\right)$ and the NTG $\left(0.18 \pm 0.04 \mathrm{nmol} \mathrm{L}^{-1} \mathrm{~h}^{-1}\right)$ regions. However, rates of microbial methanol dissimilation determined in the oligotrophic waters of the NTG $\left(0.18 \pm 0.04 \mathrm{nmol} \mathrm{L}^{-1} \mathrm{~h}^{-1}\right)$ and SG $\left(0.24 \pm 0.12 \mathrm{nmol} \mathrm{L}^{-1} \mathrm{~h}^{-1}\right)$ regions were comparable with rates in the ST region $\left(0.20 \pm 0.05 \mathrm{nmol} \mathrm{L}^{-1} \mathrm{~h}^{-1}\right)$, with the EQU exhibiting the lowest average rates of $0.11 \pm$ $0.03 \mathrm{nmol} \mathrm{L}^{-1} \mathrm{~h}^{-1}$.

Overall, latitudinal trends in depth profiles for methanol dissimilation rates mirrored those found in surface waters. Surface microbial methanol dissimilation rates determined from pre-dawn $(x)$ water were compared to those from $200 \mathrm{~m}$ $(y)$, which are in permanent darkness (the deepest $1 \%$ PAR equivalent depth of $175 \mathrm{~m}$ was found in the $\mathrm{SG}$ at $\sim 19.50^{\circ} \mathrm{S}$ ) and also showed a $\sim 1: 1$ relationship $(y=0.967 x, r=$ 0.9237, $n=19, P<0.001$ ). 

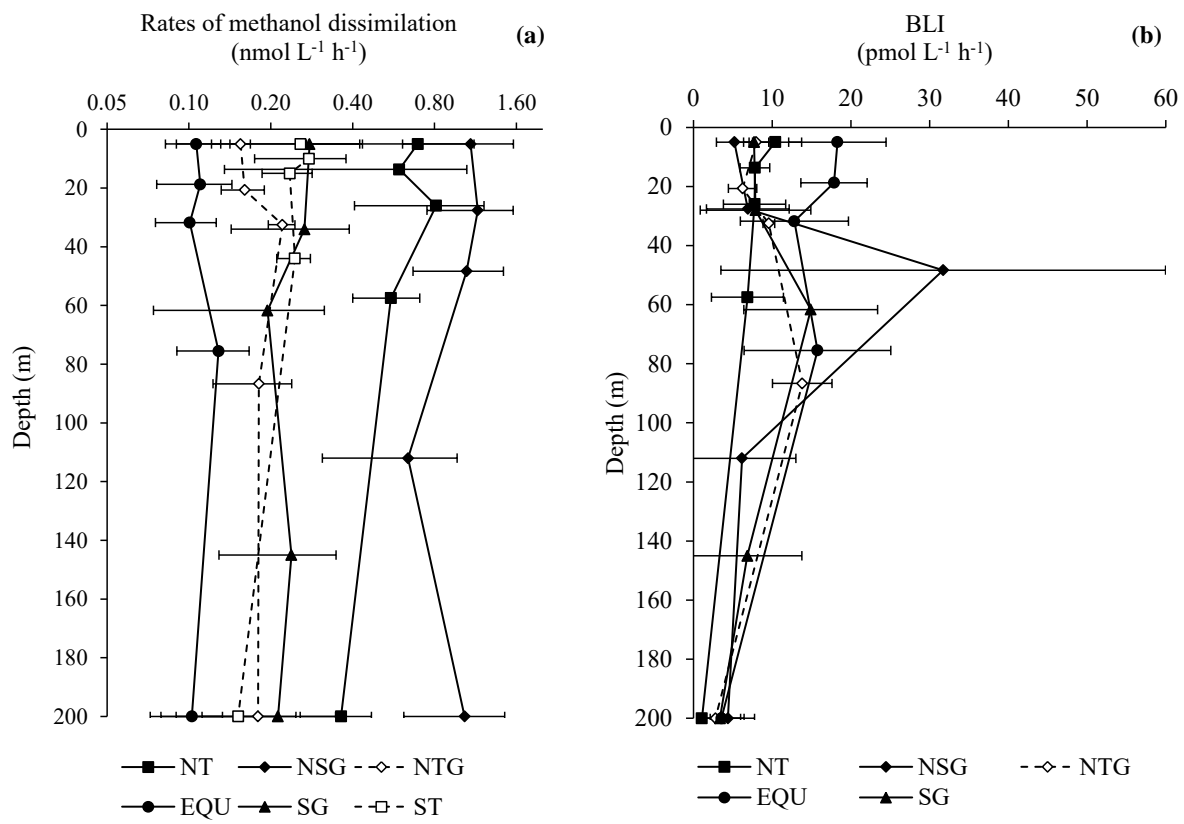

Figure 3. Average depth profiles in Atlantic provinces for (a) microbial methanol dissimilation (using the specific activity of ${ }^{14} \mathrm{CH}_{3} \mathrm{OH}$ ) and (b) bacterial leucine incorporation (BLI) in pre-dawn waters. Error bars represent \pm 1 SD of variation within the province, province averages derived from NT $(n=5)$, NSG $(n=5)$, NTG $(n=3)$, EQU $(n=4), \mathrm{SG}(n=5)$ and ST $(n=3)$, except for BLI where there is no data from the ST.

\subsection{Bacterial leucine incorporation rates}

\subsubsection{Surface}

Rates of bacterial leucine incorporation (BLI) varied between 2.9 and $25.2 \mathrm{pmol} \mathrm{L}^{-1} \mathrm{~h}^{-1}$ in the pre-dawn surface waters of the Atlantic transect (Fig. 2b). On average, surface rates of BLI were highest in the relatively more productive EQU region $\left(18.3 \pm 4.8 \mathrm{pmol} \mathrm{L}^{-1} \mathrm{~h}^{-1}\right)$, and lowest in the NSG $\left(5.2 \pm 2.3 \mathrm{pmol} \mathrm{L}^{-1} \mathrm{~h}^{-1}\right)$. Surface rates of BLI averaged $7.8 \pm 2.3$ and $7.7 \pm 2.4 \mathrm{pmol} \mathrm{L}^{-1} \mathrm{~h}^{-1}$ in the NTG and SG regions, respectively. The one measurement of BLI in the ST suggested much higher rates $\left(25.2 \mathrm{pmol} \mathrm{L}^{-1} \mathrm{~h}^{-1}\right)$ than previously determined during the transect, even when compared to the NT region $\left(9.9 \pm 3.9 \mathrm{pmol} \mathrm{L}^{-1} \mathrm{~h}^{-1}\right)$. Pre-dawn (dark) rates of BLI generally exhibited a similar latitudinal pattern to those from solar noon (light), with more variability between light and dark sampling observed in the waters of the productive EQU region. Bacterial rates of leucine incorporation determined from samples collected at solar noon $(y)$ were approximately $20 \%$ less than those determined at predawn $(y=0.7815 x, r=0.7288, n=22, P<0.001)$, perhaps reflecting a degree of light inhibition of heterotrophic bacterial production.

\subsubsection{Depth profiles}

Rates of bacterial leucine incorporation varied between 0.5 and $60.2 \mathrm{pmol} \mathrm{L}^{-1} \mathrm{~h}^{-1}$ throughout the top $200 \mathrm{~m}$ of the water column. In the sunlit depths (97\%-1\% PAR) BLI rates generally followed the pattern $\mathrm{EQY}>\mathrm{NTG} \approx \mathrm{SG}>\mathrm{NT}>\mathrm{NSG}$ (excluding the outliers of 60.2 and $31.3 \mathrm{pmol} \mathrm{L}^{-1} \mathrm{~h}^{-1}$ observed for the NSG at $14 \%$ PAR from two depth profiles in this province). This trend differs slightly from that observed for surface-only data due to subsurface (1\%-14\% PAR) maxima observed in both the north and south oligotrophic gyres (NSG, NTG, SG). In the NT, NTG and EQU provinces, BLI rates were generally higher in sunlit depths compared to the dark at $200 \mathrm{~m}$ (Fig. 3b). However, there were no statistical differences between the provinces for rates of BLI determined at $200 \mathrm{~m}$.

\subsection{Bacterial community composition}

\subsubsection{Surface}

The total number of OTUs sequenced throughout the Atlantic Ocean varied between 91 and 207. Overall, the largest contributors to surface bacterial communities were Prochlorococcus and SAR11 16S rRNA gene sequences (Fig. 5a); which together accounted for between $21 \%$ and $60 \%$ of all OTUs ( $21 \%$ in the SG and $60 \%$ in the NSG). These bacteria typically numerically dominate surface waters of nutrientdepleted oceanic regions, e.g. Gómez-Pereira et al. (2013). The numbers of Prochlorococcus, determined via flow cytometry, for the same surface samples from which 16S rRNA genes were amplified range between $0.81 \times 10^{5}$ for the NTG 


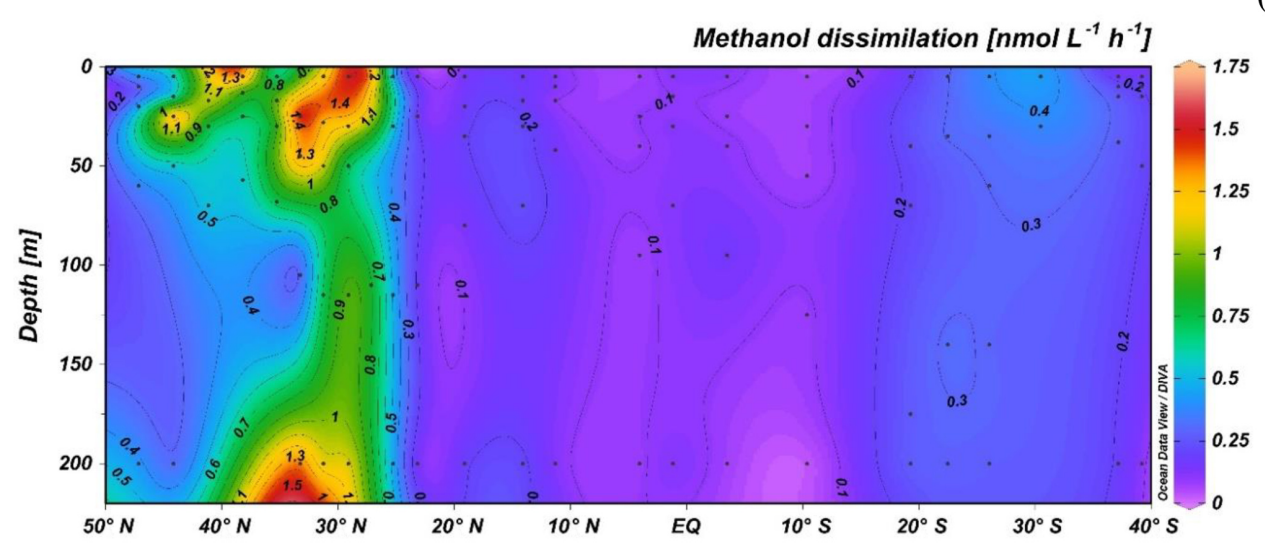

(a)

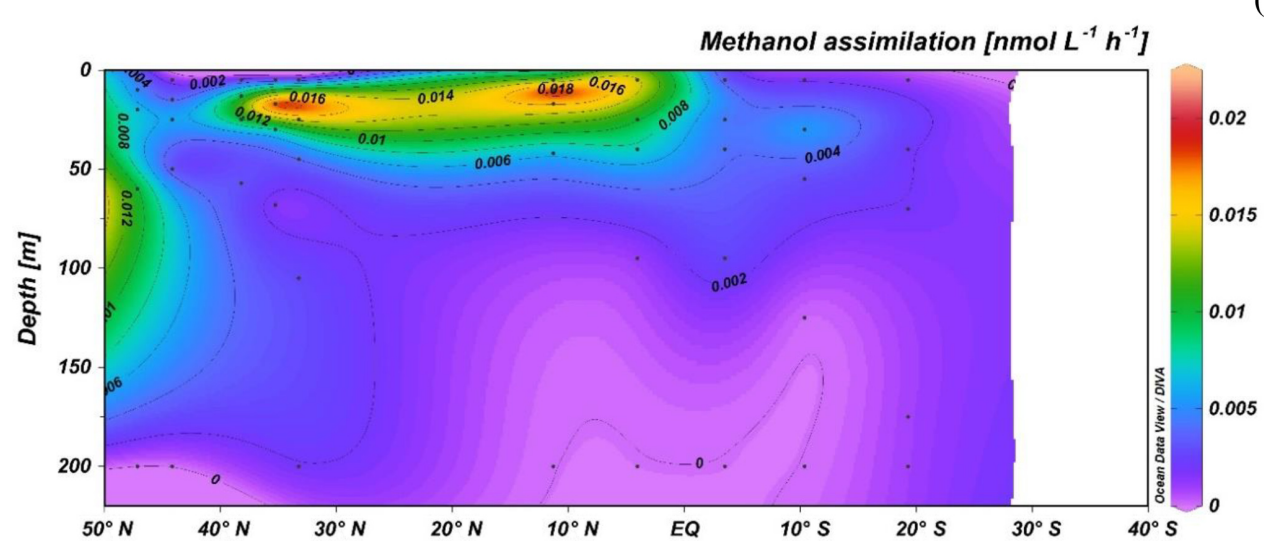

Figure 4. Microbial methanol (a) dissimilation and (b) assimilation rates (nmol L ${ }^{-1} \mathrm{~h}^{-1}$ ) in the top $200 \mathrm{~m}$ of an Atlantic Meridional Transect voyage (contour plots).

region and $3.10 \times 10^{5}$ cells $\mathrm{mL}^{-1}$ for the EQU region (see Table 1 for summary). Prochlorococcus $16 \mathrm{~S}$ rRNA gene sequences contributed an average of $28 \% \pm 12 \%$ of the community composition of surface samples throughout the surface Atlantic Ocean. Numbers of SAR11 16S rRNA gene sequences contributed a maximum of $24 \%$ to the total $16 \mathrm{~S}$ rRNA gene sequences for the NSG region, and overall contributed an average of $11 \% \pm 3 \%$ to the bacterial community in surface waters of the Atlantic Ocean. There was a clear shift between surface bacterial communities in the two northern gyre provinces with Prochlorococcus and SAR11 16S rRNA gene sequences decreasing from the NSG to the NTG region $(59 \%$ and $33 \%$ of total $16 \mathrm{~S}$ rRNA gene sequences, respectively). Oceanspirillales and Flavobacterales 16S rRNA gene sequences contributed approximately double the amount (compared to the total 16S rRNA sequences) in the NTG compared to the NSG region ( $25 \%$ and $12 \%$, respectively).

Microbial communities of the surface waters of the NT, NSG and EQU provinces were dominated by Prochlorococcus, Alteromonadales and SAR11, together representing between $64 \%$ and $72 \%$ of $16 \mathrm{~S}$ rRNA gene sequences. These orders were less dominant in the more oligotrophic waters of the NTG and SG, accounting for $43 \%$ and $34 \%$ of $16 \mathrm{~S}$ rRNA gene sequences, respectively. In these oligotrophic regions (NTG and SG) microbial communities appear less dominated by a few orders, with a more even spread of bacterial orders contributing to the community composition (Fig. 5a).

\subsubsection{Depth profiles}

The largest contributors to bacterial communities at the $33 \%$ PAR depths were, like surface communities, Prochlorococcus and SAR11 16S rRNA gene sequences (Fig. 5b). Together they accounted for between $47 \%$ and $70 \%$ of all OTUs, with the minimum and maximum contributions in the SG and EQU provinces, respectively. If the proportion of sequences contributing individually $<5 \%$ were included, then collectively they accounted for between $69 \%$ and $91 \%$ of all $16 \mathrm{~S}$ rRNA gene sequences. The main differences between the surface and $33 \%$ PAR equivalent depth (14-31 m) are the increasing dominance of the cyanobacteria Prochlorococcus, and the decrease in relative contribution of Alteromonadales at $33 \%$ PAR depths, particularly in the NT region. 

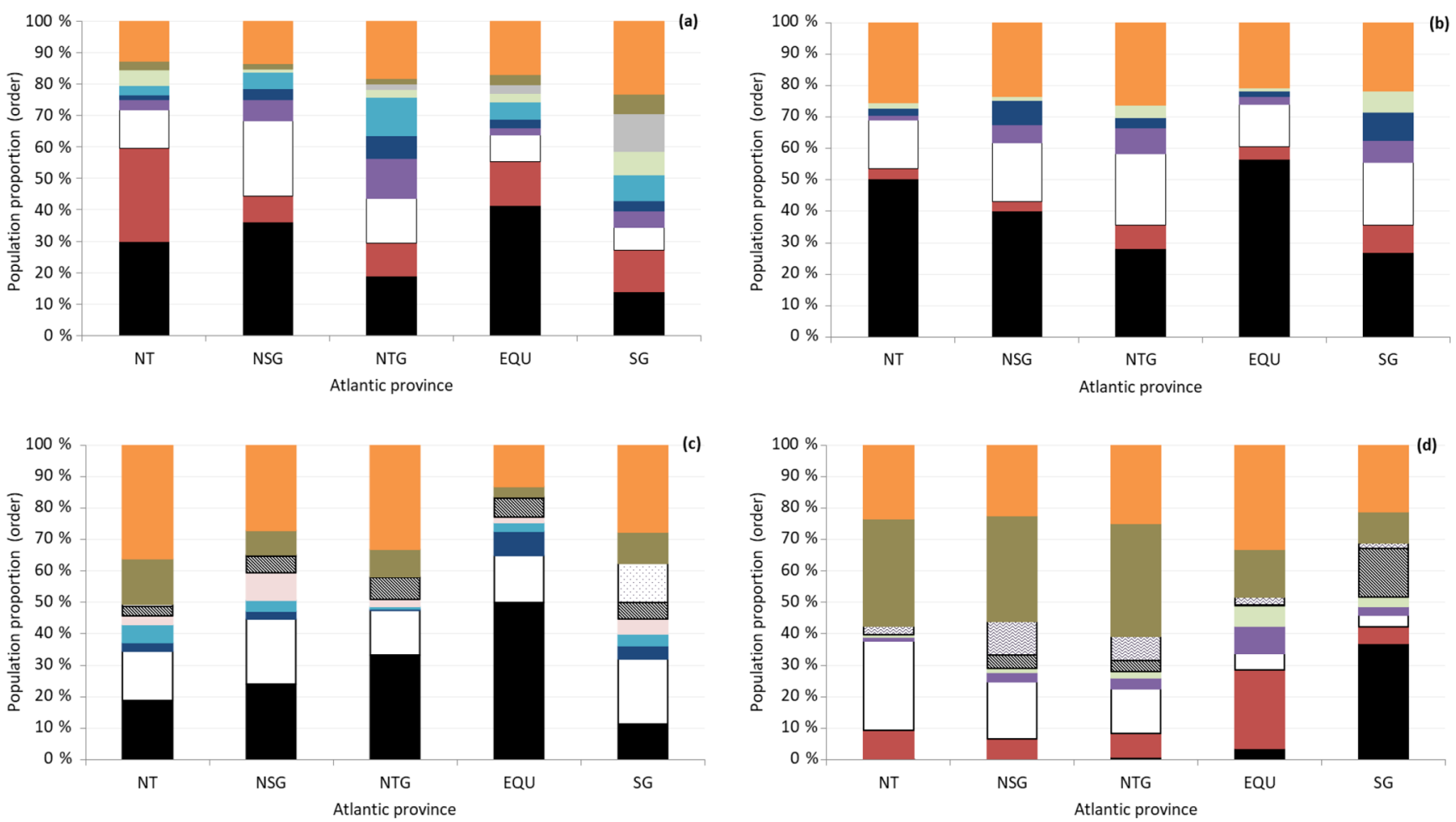

Figure 5. Changes in bacterial community composition (order, identified using 16S rRNA gene sequencing) for (a) $97 \%$ PAR surface $5 \mathrm{~m}$, (b) $33 \%$ PAR 10-31 m, (c) 1\% PAR 15-54 m and (d) $200 \mathrm{~m}$ for different provinces (NT, NSG, NTG, EQU and SG) of the Atlantic Ocean. Analysis is based on a rarefied sample of 386 sequences per sample. Bacterial orders individually contributing to less than $5 \%$ of the total sample sequences were pooled together into "Others $(<5 \%)$ " for clarity. Where $\boldsymbol{\square}$ Prochlorococcus, $\square$ Alteromonadales, $\square$ SAR11 clade, $\square$ Oceanospirillales, $\square$ Rhodospirillales, $\square$ Flavobacteriales, $\square$ Rhodobacterales, $\square$ Sphingomonadales, $\square$ Synechococcus, $\sqsubset$ Acidimicrobiales, Order III 图 Incertae Sedis, $\square$ SAR324 clade (marine group B), $\square$ uncultivated bacterium and other bacteria individually comprising $<5 \%$.

In the darker $1 \%$ PAR depths $(59-127 \mathrm{~m})$ Prochlorococcus and SAR11 16S rRNA gene sequences (Fig. 5c) still accounted for between $32 \%$ and $65 \%$ of all OTUs, with the minimum and maximum contributions in the SG and EQU, respectively. With the addition of sequences for each Order contributing $<5 \%$ to the total 16SrRNA gene sequences, these three categories accounted for $60 \%-81 \%$ of all $16 \mathrm{~S}$ rRNA gene sequences retrieved throughout each of the regions sampled. Two notable differences at this light level in the SG region compared to the other provinces are the $12 \%$ contribution made by the Order III Incertae Sedis which belongs to the Bacteroidetes class, and the relative reduction in contribution made by Prochlorococcus (11\% compared to an Atlantic average of $27 \% \pm 15 \%$ at $1 \%$ PAR). However, the latter trend is not confirmed in the cell numbers of Prochlorococcus determined via flow cytometry (Table 1 ).

In the permanent dark of $200 \mathrm{~m}$, SAR11 bacteria contributed between $14 \%$ and $29 \%$ in northern regions, which contrasted to only between $4 \%$ and $5 \%$ in the EQU and SG provinces. The SAR324 clade contributed $8 \%-11 \%$ in the northern gyre. Both uncultivated bacteria and those that individually comprised $<5 \%$ contributed relatively highly to the
OTUs (10\%-36\% and $21 \%-33 \%$, respectively). These two groupings together with the SAR11 and SAR324 make up $83 \%-89 \%$ in northern regions and between $37 \%$ and $56 \%$ in the SG and EQU provinces, respectively. For the EQU region the Alteromonadales order is also significant at $25 \%$ (which collectively comprise $81 \%$ of all OTUs for EQU), whilst for the SG the cyanobacteria Prochlorococcus and Synechococcus comprise $52 \%$ (which collectively comprise $89 \%$ of all OTUs for SG).

\section{Discussion}

\subsection{Basin-scale variability in biological methanol uptake}

Maximum rates of methanol dissimilation in the Atlantic Ocean were recorded in the NSG province at $33 \%$ PAR light depth $\left(25 \mathrm{~m}, 1.68 \mathrm{nmol} \mathrm{L}^{-1} \mathrm{~h}^{-1}\right.$, Figs. 2 and 4a). An overview of the variation in rates of methanol dissimilation to $\mathrm{CO}_{2}$ throughout the top $200 \mathrm{~m}$ of the water column in the Atlantic Ocean is shown in Fig. 4a, which illustrates subsurface maxima in northerly latitudes. However, no statistically significant differences were found between rates 
of methanol dissimilation in the euphotic zone $(97 \%-1 \%$ PAR) compared to the aphotic zone (samples from $200 \mathrm{~m}$ ) in the NSG $\left(t_{\mathrm{NSG}}=2.63, t_{20}=2.85\right.$ for $\left.P<0.01\right)$, NTG $\left(t_{\mathrm{NTG}}=0.02, t_{12}=3.05\right.$ for $\left.P<0.01\right), \mathrm{EQU}\left(t_{\mathrm{EQU}}=1.01\right.$, $t_{18}=2.88$ for $\left.P<0.01\right)$ and SG regions $\left(t_{\mathrm{SG}}=0.88, t_{19}=\right.$ 2.88 for $P<0.01)$. This is consistent with a previous study in the north-east Atlantic Ocean, which similarly reported no significant variability in methanol dissimilation rates with depth (Dixon and Nightingale, 2012). Nevertheless, greater variability with depth was observed for methanol dissimilation rates from the northern gyre $\left(F_{\mathrm{NSG}}=3.22\right.$ where $F_{3,17}=3.20, P<=0.05$ and $F_{\mathrm{NTG}}=5.14$ where $F_{2,10}=$ 4.10, $P<0.05)$. Variability in rates from the euphotic zone were found to be significantly higher than those from $200 \mathrm{~m}$ in northern $\left(t_{\mathrm{NT}}=3.17, t_{20}=2.85\right.$ for $\left.P<0.01\right)$ and southern temperate regions $\left(t_{\mathrm{ST}}=5.03, t_{10}=3.17\right.$ for $P<0.01$ ).

Although the highest rates of methanol dissimilation were determined in the NSG, these values were approximately 7 times lower than the maxima determined during a seasonal study of the temperate western English Channel (0.5-11.2 $\mathrm{nmol} \mathrm{L}^{-1} \mathrm{~h}^{-1}$; Sargeant et al., 2016). Rates determined in the temperate waters of the South Atlantic (0.11-0.45 $\mathrm{nmol} \mathrm{L}^{-1} \mathrm{~h}^{-1}$ ) are most comparable to the lowest rates determined during late spring and early summer of $\sim 0.50 \mathrm{nmol} \mathrm{L}^{-1} \mathrm{~h}^{-1}$ in temperate northern coastal waters (Sargeant et al., 2016). The seasonal study in the western English Channel showed maximum rates of up to $11.2 \mathrm{nmol} \mathrm{L}^{-1} \mathrm{~h}^{-1}$ during autumn and winter months (Sargeant et al., 2016). The differences in methanol dissimilation rates between the temperate waters of the North Atlantic $\left(0.83 \pm 0.42 \mathrm{nmol} \mathrm{L}^{-1} \mathrm{~h}^{-1}\right)$ and South Atlantic $(0.27 \pm$ $\left.0.13 \mathrm{nmol} \mathrm{L}^{-1} \mathrm{~h}^{-1}\right)$ may therefore reflect seasonal differences between hemispheres, i.e. sampling in the NT region occurred during late autumn compared to late spring in the ST region.

Methanol assimilation rates were generally 2 orders of magnitude lower than dissimilation rates, reaching a maximum of $0.028 \mathrm{nmol} \mathrm{L}^{-1} \mathrm{~h}^{-1}$ in the top $200 \mathrm{~m}$ throughout the Atlantic Ocean (Fig. 4b). Rates of methanol assimilation exhibited subsurface maxima (at $33 \%$ PAR equivalent depth) which were particularly evident just north of the Equator (EQU) and in the northern gyre (NSG) of $0.015 \pm$ $0.004 \mathrm{nmol} \mathrm{L}^{-1} \mathrm{~h}^{-1}$. These subsurface rates were on average higher than surface values $\left(0.004 \pm 0.004 \mathrm{nmol} \mathrm{L}^{-1} \mathrm{~h}^{-1}\right)$. Results are similar to findings by Dixon and Nightingale (2012) who also demonstrated subsurface maxima between 20 and $30 \mathrm{~m}$ in the north-east Atlantic. The methanol assimilation rates are shown for direct comparison to dissimilation, but have been previously discussed in more detail in Dixon et al. (2013).

\subsection{Bacterial community and productivity}

In contrast to microbial methanol dissimilation, rates of bacterial leucine incorporation were lowest in the northern oligotrophic gyre (NSG $5.2 \pm 2.3 \mathrm{pmol} \mathrm{L}^{-1} \mathrm{~h}^{-1}$, NTG $7.8 \pm$ $2.3 \mathrm{pmol} \mathrm{L}^{-1} \mathrm{~h}^{-1}$ ) reflecting lower microbial activity in these regions of the Atlantic. Surface microbial methanol dissimilation rates exhibited a statistically significant inverse correlation with bacterial leucine incorporation, $(r=-0.351$, $n=36, P \leq 0.05$ ). This is consistent with findings from a seasonal study in the western English Channel, where surface rates of methanol dissimilation were also inversely correlated to bacterial production (Sargeant et al., 2016). For all the depth data, a negative correlation was also found in the NTG, EQU and SG regions $(r=-0.372, n=52$, $P \leq 0.01$ ), but NT and NSG areas showed methanol dissimilation rates independent of BLI. The productivity of heterotrophic bacteria is generally associated with the concentrations of phytoplankton-derived dissolved organic matter (DOM), e.g. proteins, lipids and carbohydrates which are utilised as sources of energy and carbon (Ogawa and Tanoue, 2003; Nagata, 2008; Benner and Herndl, 2011). Results from this present study indicate that in regions of low heterotrophic bacterial production, i.e. in the North Atlantic Gyre (minimum rate of bacterial leucine incorporation of $3 \mathrm{pmol} \mathrm{L}^{-1} \mathrm{~h}^{-1}$ ) rates of methanol dissimilation were relatively higher. In oligotrophic regions, phytoplanktonderived DOM is scarce, suggesting that those bacteria able to metabolise methanol are using the carbon from methanol as an alternative source of energy (and to a lesser extent carbon).

Although the bacterial community $16 \mathrm{~S}$ rRNA gene sequence data did not display any clear patterns with changing biogeochemical province (in contrast to microbial methanol dissimilation rates), the bacterial community was shown to be depth-stratified throughout the Atlantic Ocean (Fig. 6a). A nonmetric multi-dimensional scale (MDS) plot of a Bray-Curtis similarity matrix of 16S rRNA gene sequences (Fig. 6a) found bacterial community samples to cluster into three distinct groupings possibly reflecting light levels: sunlit (97\% and $33 \%$ PAR), minimal light (1\% PAR) and dark $(200 \mathrm{~m})$. Bacterial community samples from the same PAR equivalent depths were found to group together regardless of biogeochemical province. A larger cluster formed of samples from $97 \%$ and $33 \%$ PAR is likely to be formed of bacterial communities originating from the well-mixed surface layer of the water column, accounting for their similarity in composition. When all environmental parameters were considered together (including bacterial numbers and BLI) a Euclidean distance matrix nonmetric MDS also demonstrated photic waters (97\%-1\% PAR) clustered together, and were significantly different to dark waters from $200 \mathrm{~m}$ (Fig. 6b). However, no significant differences were observed between rates of methanol dissimilation determined from the euphotic zone (samples from $97 \%$ to $1 \%$ PAR equivalent depths) compared to the aphotic zone (samples from $200 \mathrm{~m}$ of depth) for gyre and equatorial regions (NSG $t_{\mathrm{NSG}}=2.63$ $\left(t_{20}=2.85\right.$ for $\left.P<0.01\right)$, NTG $t_{\mathrm{NTG}}=0.02\left(t_{12}=3.05\right.$ for $P<0.01)$, EQU $t_{\mathrm{EQU}}=1.01\left(t_{18}=2.88\right.$ for $\left.P<0.01\right)$ and 


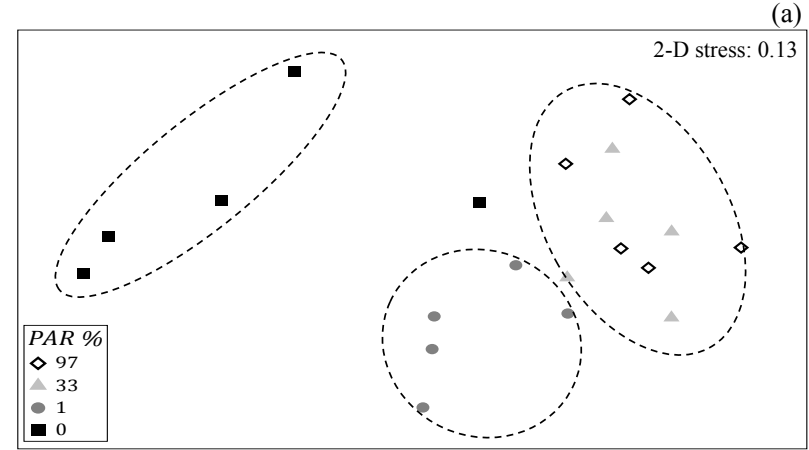

(b)

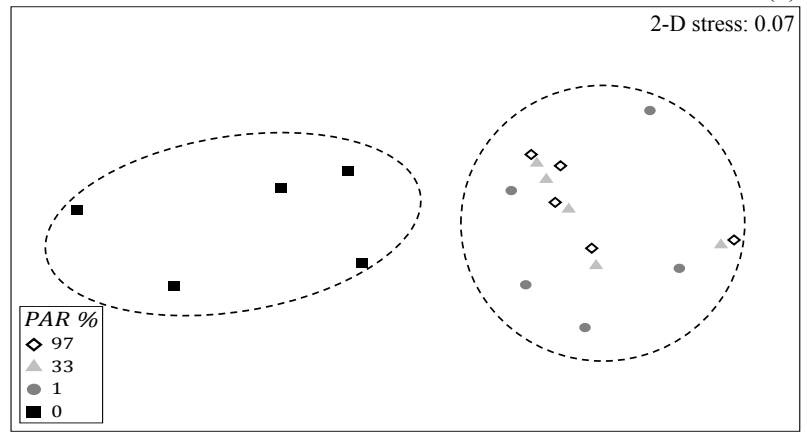

(c)

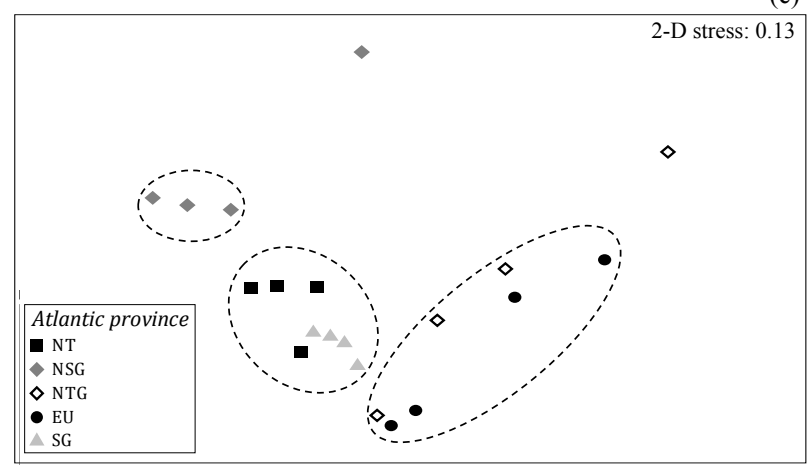

Figure 6. Nonmetric multidimensional scale (MDS) plots of (a) a Bray-Curtis similarity matrix of the 16S rRNA gene sequences of the bacterial community, (b) a Euclidean distance matrix of environmental parameters (salinity, temperature, chl $a$, primary productivity, inorganic nutrients, flow cytometry cell numbers, BLI) and (c) a Euclidean distance matrix of rates of methanol dissimilation. Dashed lines highlight significant sample groupings. Plots were generated using PRIMER-E (www.primer-e.com, last access: 21 August 2018). (a) and (b) represent samples from $200 \mathrm{~m}$, i.e. $0 \%$ PAR.

SG $t_{S G}=0.88\left(t_{19}=2.88\right.$ for $\left.\left.P<0.01\right)\right)$ although, clear differences between provinces were evident (Fig. 6c). This is consistent with results from Dixon and Nightingale (2012) who also found no significant variation of methanol dissimilation with depth in the north-east Atlantic Ocean. These data suggest that light levels do not have a strong role to play in microbial methanol dissimilation in waters of the Atlantic, despite the overall bacterial community showing strong vari- ability with depth (or incident light). Depth-stratification of microbial communities has been observed previously by Carlson et al. (2004), DeLong et al. (2006) and between euphotic and aphotic zones in the north-western Sargasso Sea (Carlson et al., 2004). Heywood et al. (2006) suggested that the physical separation of nutrient-poor surface waters in gyre regions from mixing with more nutrient-rich waters below a defined pycnocline, in combination with differing levels of light availability, could partially explain changes in bacterial community composition throughout the water column. Therefore, these results could indicate that methanol dissimilation is limited to specific microbial groups that are present relatively uniformly between the surface and $200 \mathrm{~m}$, although more depth variability is shown north of $25^{\circ} \mathrm{N}$ where rates of methanol dissimilation are the highest and most variable.

\subsection{Methanol dissimilation and SAR11}

SAR11 cells have been shown to utilise methanol, but only as a source of energy (Sun et al., 2011). The numbers of SAR11 16S rRNA gene sequences exhibited a statistically significant correlation with rates of microbial methanol dissimilation throughout the Atlantic basin $(r=0.477, n=$ $20, P<0.05)$, where the number of SAR11 16S rRNA gene sequences explained approximately half of the spatial variability in rates of methanol dissimilation. It should be noted that this correlation has been made with amplicon ratios, relating to the relative success of SAR11 in the community, rather than with SAR11 cell numbers specifically. In culture, SAR11 cells (strain HTCC1062) have previously been shown to utilise methanol as a source of energy at a rate of $\sim 5 \times 10^{-20}$ moles cell ${ }^{-1} \mathrm{~h}^{-1}$ (Sun et al., 2011), which equates to $2 \mathrm{nmol} \mathrm{L}^{-1} \mathrm{~h}^{-1}$ (using a culture cell abundance of $4 \times 10^{7}$ cells mL ${ }^{-1}$; Sun et al., 2011). SAR11 cells dominate $(59 \pm 4 \%)$ the low nucleic acid (LNA) fraction of bacterioplankton consistently across the Atlantic Ocean, where typically numbers of LNAs range between 0.2 and $1.0 \times 10^{9}$ cells L $^{-1}$ (Mary et al., 2006a). Thus estimates of in situ SAR11 numbers range between 0.12 and $0.59 \times 10^{9}$ cells L $^{-1}$. This is consistent with estimates from the Sargasso Sea of $\sim 0.1 \times 10^{9}$ cells L ${ }^{-1}$ (where they are reported to contribute $\sim 25 \%$ of total prokaryotic abundance of $0.4 \times 10^{6}$ cells mL ${ }^{-1}$; Malmstrom et al., 2004). Thus, we estimate that SAR11 cells of the Atlantic Ocean could be oxidising methanol at rates between 5 and $29.5 \mathrm{pmol} \mathrm{L}^{-1} \mathrm{~h}^{-1}$, which could account for between $0.3 \%$ and $59 \%$ of the rates of methanol dissimilation in surface Atlantic waters.

A seasonal investigation in the western English Channel reported bacterial numbers ranging between 2.0 and $15.8 \times 10^{5}$ cells $\mathrm{mL}^{-1}$ (Sargeant et al., 2016) which agrees well with data from Mary et al. (2006b) (2.0 $16.0 \times 10^{5}$ cells $\left.\mathrm{mL}^{-1}\right)$. Assuming that SAR11 contribute between $9 \%$ and $20 \%$ of total bacterioplankton (Mary et al., 2006b) suggests SAR11 numbers range between 0.18 
Table 1. Summary of rates of methanol uptake (dissimilation and assimilation), methanol concentrations, bacterial leucine incorporation (BLI) and production (BP), numbers of heterotrophic bacteria (BN), Prochlorococcus (Pros) and Synechococcus (Syns). Values given are average \pm standard deviation (range). NA denotes that data are not available.

\begin{tabular}{|c|c|c|c|c|c|c|c|}
\hline & \multirow[b]{2}{*}{ Overall } & \multicolumn{6}{|c|}{ Atlantic province } \\
\hline & & NT & NSG & NTG & EQU & SG & ST \\
\hline $\begin{array}{l}\text { Methanol dissimilation } \\
\left(\mathrm{nmol} \mathrm{L}^{-1} \mathrm{~h}^{-1}\right)\end{array}$ & $\begin{array}{l}0.45 \pm 0.42 \\
(0.01-1.68)\end{array}$ & $\begin{array}{l}0.69 \pm 0.35 \\
(0.22-1.50)\end{array}$ & $\begin{array}{l}0.99 \pm 0.41 \\
(0.15-1.68)\end{array}$ & $\begin{array}{l}0.18 \pm 0.04 \\
(0.10-0.25)\end{array}$ & $\begin{array}{l}0.11 \pm 0.03 \\
(0.07-0.17)\end{array}$ & $\begin{array}{l}0.24 \pm 0.12 \\
(0.01-0.45)\end{array}$ & $\begin{array}{l}0.20 \pm 0.05 \\
(0.11-0.27)\end{array}$ \\
\hline 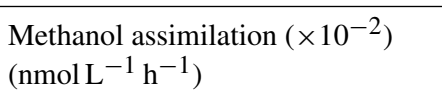 & $\begin{array}{l}0.51 \pm 0.54 \\
(0.00-2.24)\end{array}$ & $\begin{array}{l}0.54 \pm 0.53 \\
(0.00-2.23)\end{array}$ & $\begin{array}{l}0.53 \pm 0.56 \\
(0.17-1.51)\end{array}$ & NA & $\begin{array}{l}0.67 \pm 0.66 \\
(0.00-2.24)\end{array}$ & $\begin{array}{l}0.19 \pm 0.16 \\
(0.00-0.57)\end{array}$ & NA \\
\hline $\mathrm{BLI}\left(\mathrm{pmol} \mathrm{L}^{-1} \mathrm{~h}^{-1}\right)$ & $\begin{array}{r}9.4 \pm 8.9 \\
(0.5-60.2)\end{array}$ & $\begin{array}{r}7.7 \pm 4.0 \\
(0.9-14.2)\end{array}$ & $\begin{array}{l}9.7 \pm 14.2 \\
(1.0-60.2)\end{array}$ & $\begin{array}{r}8.0 \pm 4.3 \\
(2.0-17.0)\end{array}$ & $\begin{array}{l}13.7 \pm 7.9 \\
(0.6-26.4)\end{array}$ & $\begin{array}{r}8.2 \pm 9.5 \\
(0.5-41.5)\end{array}$ & NA \\
\hline${ }^{\mathrm{a}} \mathrm{BP}(\mathrm{TCF})\left(\mathrm{ng} \mathrm{CL}^{-1} \mathrm{~h}^{-1}\right)$ & $\begin{array}{r}14.6 \pm 13.8 \\
(0.8-96.1)\end{array}$ & $\begin{array}{l}11.9 \pm 6.1 \\
(1.5-22.0)\end{array}$ & $\begin{array}{r}15.0 \pm 21.9 \\
(1.5-96.1)\end{array}$ & $\begin{array}{l}12.4 \pm 6.6 \\
(3.2-26.3)\end{array}$ & $\begin{array}{r}21.2 \pm 12.2 \\
(1.0-41.0)\end{array}$ & $\begin{array}{r}12.7 \pm 14.8 \\
(0.8-64.3)\end{array}$ & NA \\
\hline${ }^{b} \mathrm{BP}(\mathrm{ECF})\left(\mathrm{ng} \mathrm{CL}^{-1} \mathrm{~h}^{-1}\right)$ & $\begin{array}{r}4.8 \pm 4.6 \\
(0.3-31.6)\end{array}$ & $\begin{array}{l}3.9 \pm 2.0 \\
(0.5-7.2)\end{array}$ & $\begin{array}{r}4.9 \pm 7.2 \\
(0.5-31.6)\end{array}$ & $\begin{array}{l}4.1 \pm 2.2 \\
(1.0-8.7)\end{array}$ & $\begin{array}{r}7.0 \pm 4.0 \\
(0.3-13.5)\end{array}$ & $\begin{array}{r}4.2 \pm 4.9 \\
(0.3-21.1)\end{array}$ & NA \\
\hline $\begin{array}{l}\text { Numbers of heterotrophic bacteria } \\
\left(\times 10^{5} \text { cells } \mathrm{mL}^{-1}\right)\end{array}$ & $\begin{array}{r}6.5 \pm 6.3 \\
(1.4-82.6)\end{array}$ & NA & NA & $\begin{array}{l}5.8 \pm 2.0 \\
(1.6-9.8)\end{array}$ & $\begin{array}{l}8.8 \pm 10.3 \\
(1.4-82.6)\end{array}$ & $\begin{array}{r}5.4 \pm 4.4 \\
(1.5-35.8)\end{array}$ & NA \\
\hline $\begin{array}{l}\text { Numbers of Prochlorococcus sp. } \\
\left(\times 10^{5} \text { cells } \mathrm{mL}^{-1}\right)\end{array}$ & $\begin{array}{r}1.12 \pm 4.62 \\
(0.0-4.62)\end{array}$ & $\begin{array}{r}0.91 \pm 0.07 \\
(0.0-2.56)\end{array}$ & $\begin{array}{r}0.89 \pm 0.71 \\
(0.0-4.21)\end{array}$ & $\begin{array}{r}1.52 \pm 1.23 \\
(0.0-4.19)\end{array}$ & $\begin{array}{l}1.67 \pm 0.2 \\
(0.0-4.62)\end{array}$ & $\begin{array}{r}1.20 \pm 0.01 \\
(0.0-2.45)\end{array}$ & $\begin{array}{r}0.35 \pm 0.22 \\
(0.0-2.33)\end{array}$ \\
\hline $\begin{array}{l}\text { Numbers of Synechococcus } \mathrm{sp} \text {. } \\
\left(\times 10^{4} \text { cells } \mathrm{mL}^{-1}\right)\end{array}$ & $\begin{array}{r}1.64 \pm 31.4 \\
(0.0-31.4)\end{array}$ & $\begin{array}{r}1.96 \pm 3.61 \\
(0.0-12.7)\end{array}$ & $\begin{array}{r}0.18 \pm 0.21 \\
(0.0-0.93)\end{array}$ & $\begin{array}{r}0.15 \pm 0.17 \\
(0.0-0.73)\end{array}$ & $\begin{array}{r}1.34 \pm 2.69 \\
(0.0-12.8)\end{array}$ & $\begin{array}{r}0.14 \pm 0.13 \\
(0.0-0.79)\end{array}$ & $\begin{array}{l}8.30 \pm 10.3 \\
(0.02-31.4)\end{array}$ \\
\hline${ }^{\mathrm{c}}$ Methanol (nM) & $\begin{array}{l}143 \pm 82 \\
(38-420)\end{array}$ & $\begin{array}{r}110 \pm 126 \\
(38-420)\end{array}$ & $\begin{array}{r}203 \pm 38 \\
(154-281)\end{array}$ & $\begin{array}{r}193 \pm 46 \\
(148-278)\end{array}$ & $\begin{array}{r}148 \pm 37 \\
(117-241)\end{array}$ & $\begin{array}{l}110 \pm 33 \\
(58-176)\end{array}$ & 132 \\
\hline
\end{tabular}

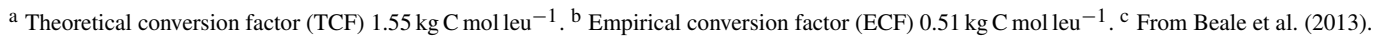

$3.16 \times 10^{5}$ cells $\mathrm{mL}^{-1}$ at this coastal site. Using the above estimate of $\sim 5 \times 10^{-20}$ moles cell ${ }^{-1} \mathrm{~h}^{-1}$ for rates of methanol dissimilation in cultured SAR11 cells suggests that SAR11 could oxidise methanol at rates ranging between 0.9 and $15.8 \mathrm{pmol} \mathrm{L}^{-1} \mathrm{~h}^{-1}$ in temperate coastal regions. This equates to $<0.01 \%-2.3 \%$ of microbial community methanol dissimilation rates $\left(0.7-11.2 \mathrm{nmol} \mathrm{L}^{-1} \mathrm{~h}^{-1}\right.$; Sargeant et al., 2016). Therefore, we suggest that cells of the SAR11 clade are more likely to make a larger contribution to marine microbial methanol dissimilation in open ocean environments, where alternative sources of carbon are more limited relative to temperate coastal waters. More work is required to add clarity and understanding to the role that SAR11 cells play in marine community methanol dissimilation.

Previously, methylotrophic bacteria such as Methylophaga sp., Methylococcaceae sp. and Hyphomicrobium sp. have been identified, using $m x a F$ functional gene primers (which encode for the classical methanol dehydrogenase), from the same DNA samples analysed for 16S rRNA genes in this study, from the upper water column of Atlantic Ocean provinces (Dixon et al., 2013). Although numerically very rare (1-11 16S rRNA gene sequences per sample), 16S rRNA gene sequences identified as Methylophaga spp., Methylophaga sp. DMS021 (EU001861) and uncul- tured Methylophaga sp. (EU031899), were found in each of the Atlantic Ocean provinces in this study (at $97 \%$ PAR or $200 \mathrm{~m}$ of depth), consistent with previous identification of Methlophaga spp. in these Atlantic provinces using mxaF gene cloning (Dixon et al., 2013). More recently the xoxF gene, which encodes an alternative methanol dehydrogenase, has also been found to be widespread in coastal marine environments (Taubert et al., 2015). SAR11 bacteria are thought to contain an $\mathrm{Fe}$ alcohol dehydrogenase, which although not specific for methanol, can oxidise methanol (and other short chain alcohols) to formaldehyde which is then thought to be converted to $\mathrm{CO}_{2}$ by a tetrahydrofolate-linked $\mathrm{C}_{1}$ transfer pathway to produce energy (Sun et al., 2011). Thus it seems likely that both methylotrophic bacteria possessing $m x a F$ and/or $x o x F$, together with microbes such as SAR11 (Sun et al., 2011), are largely responsible for the turnover of methanol in seawater.

Members of Betaproteobacteria, OM43, have been shown to be potentially important obligate methylotrophs, with cultivated cells of strain HTCC2181 dissimilating 3.5 times more methanol than was assimilated (Halsey et al., 2012). OM43 were not successfully identified in the 16S rRNA sequences in this study, which could be an artefact of the relatively low sequence coverage (386 sequences per sample) 
leading to this taxon not being detectable. During a previous coastal study, also analysing $16 \mathrm{~S}$ rRNA pyrosequence data, in the western English Channel (Sargeant et al., 2016) only a single sequence of the OM43 clade, HTCC2181, was identified. This is a limitation of this type of environmental sequencing effort and should be a consideration in planning any future projects aiming to understand microbial function through process measurements alongside the generation of metagenomic datasets.

\subsection{Marine methanol cycling}

Data from this study substantially add to the measurements of microbial methanol dissimilation rates in seawater. This extended spatial coverage clearly demonstrates that methanol dissimilation is a widespread microbial process taking place in light and dark environments throughout the Atlantic Ocean. Dissimilation rates are typically 2 orders of magnitude greater than assimilation rates across most of the Atlantic Basin. These data suggest that methanol is an important source of energy for microbes. This is particularly true in the northern oligotrophic waters of the Atlantic Ocean, where corresponding in situ methanol concentrations range between 148 and $281 \mathrm{nM}$ (Table 1). What is not clear is the source of methanol in open ocean waters, which is suspected to be biological in nature (Dixon et al., 2011a). Although direct flux estimates suggest that the atmosphere could also act as a source to the ocean (Yang et al., 2013), the magnitude of this flux is insufficient to support the observed rates of microbial methanol consumed by bacteria, and hence is suspected to be a minor contribution (Dixon et al., 2011a). Recent culture studies indicate that Prochlorococcus sp., Synechococcus sp. and Trichodesmium sp. could produce methanol (Mincer and Aicher, 2016; Halsey et al., 2017), but in situ production mechanisms are unknown. Further work is needed to fully elucidate and quantify the sources of methanol in marine waters.

\section{Conclusions}

This study reports the first basin-wide understanding of microbial methanol dissimilation rates in seawater. Radiochemical assays have demonstrated active metabolism throughout the top $200 \mathrm{~m}$ of the water column, with rates being substantially higher in the northern subtropical Atlantic gyre. Microbial methanol dissimilation rates showed a positive correlation with the numbers of SAR11 16S rRNA gene sequences, and an inverse relationship with bacterial leucine incorporation. Future work should determine marine methanol sources and understand the relative contribution of various microbial orders to methanol loss processes.

Data availability. The underlying research data comprise a part of Stephanie L. Sargeants' PhD thesis titled "Microbial utilisation of methanol in seawater" which she undertook at the Plymouth Marine Laboratory and was awarded in 2013 by the School of Life Sciences, University of Warwick http://webcat.warwick.ac.uk/record= b2724358 S1 (Sargeant, 2013).

Competing interests. The authors declare that they have no conflict of interest.

Acknowledgements. We thank all scientists, officers and crew of the RRS James Cook during JC029. We also thank Rachael Beale for determining methanol concentrations; Glen Tarran for flow cytometry data and Karen Tait, Yin Chen and Michael Cunliffe for advice with molecular biology work. Satellite data were processed by the NERC Earth Observation Data Acquisition and Analysis Service (NEODAAS) at Plymouth Marine Laboratory (http://www.neodaas.ac.uk, last access: 21 August 2018). This work was funded by the UK Natural Environmental Research Council (NERC) and the Earth and Life Systems Alliance, Norwich Research Park. This study is also a contribution to the international IMBeR project and was also supported by the UK Natural Environment Research Council National Capability funding to Plymouth Marine Laboratory and the National Oceanography Centre, Southampton. This is contribution number 323 of the AMT programme.

Edited by: Silvio Pantoja

Reviewed by: Ludmila Chistoserdova and Steve Giovannoni

\section{References}

Beale, R., Dixon, J. L., Arnold, S. R., Liss, P. S., and Nightingale, P. D.: Methanol, acetaldehyde, and acetone in the surface waters of the Atlantic Ocean, J Geophys. Res.-Oceans, 118, 5412-5425, https://doi.org/10.1002/jgrc.20322, 2013.

Benner, R. and Herndl, G.:, Bacterially derived dissolved organic matter in the microbial carbon pump, in: Microbial Carbon Pump in the Ocean, Science/AAAS, Washington, USA, 46-48, 2011.

Caporaso, J. G., Kuczynski, J., Stombaugh, J., Bittinger, K., Bushman, F. D., Costello, E. K., Fierer, N., Pena, A. G., Goodrich, J. K., Gordon, J. I., and Huttley, G. A.: QIIME allows analysis of high-throughput community sequencing data, Nat. Methods, 7, 335-336, https://doi.org/10.1038/nmeth.f.303, 2010.

Carlson, C. A., Giovannoni, S. J., Hansell, D. A., Goldberg, S. J., Parsons, R., and Vergin, K.: Interactions among dissolved organic carbon, microbial processes, and community structure in the mesopelagic zone of the northwestern Sargasso Sea, Limnol. Oceanogr., 49, 1073-1083, https://doi.org/10.4319/lo.2004.49.4.1073, 2004.

Carpenter, L. J., Archerand, S. D., and Beale, R.: Oceanatmopshere trace gas exchange, Chem. Soc. Rev., 41, 64736506, https://doi.org/10.1039/c2cs35121h, 2012.

Chistoserdova, L.: Modularity of methylotrophy, revisited, Environ. Microbiol., 13, 2603-2622, https://doi.org/10.1111/j.14622920.2011.02464.x, 2011.

Chistoserdova, L., Kalyuzhnaya, M. G., and Lidstrom M. E.: The expanding world of methylotrophic 
metabolism, Annu. Rev. Microbiol., 63, 477-499, https://doi.org/10.1146/annurev.micro.091208.073600, 2009.

DeLong, E. F., Preston, C. M., Mincer, T., Rich, V., Hallam, S. J., Frigaard, N. U., Martinez, A., Sullivan, M. B., Edwards, R., Brito, B. R., and Chisholm, S. W.: Community genomics among stratified microbial assemblages in the ocean's interior, Science, 311, 496-503, https://doi.org/10.1126/science.1120250, 2006.

Dixon, J. L. and Nightingale, P. D.: Fine-scale variability in methanol uptake and oxidation: from the microlayer to $1000 \mathrm{~m}$, Biogeosciences, 9, 2961-2972, https://doi.org/10.5194/bg-92961-2012, 2012.

Dixon, J. L., Beale, R., and Nightingale, P. D.: Rapid biological oxidation of methanol in the tropical Atlantic: significance as a microbial carbon source, Biogeosciences, 8, 2707-2716, https://doi.org/10.5194/bg-8-2707-2011, 2011a.

Dixon, J. L., Beale, R., and Nightingale, P. D.: Microbial methanol uptake in northeast Atlantic waters, ISME J., 5, 704-716, https://doi.org/10.1038/ismej.2010.169, 2011b.

Dixon, J. L., Sargeant, S., Nightingale, P. D., and Murrell, J. C.: Gradients in microbial methanol uptake: productive coastal upwelling waters to oligotrophic gyres in the Atlantic Ocean, ISME J., 7, 568-580, https://doi.org/10.1038/ismej.2012.130, 2013.

Felix, J. D., Jones, S. B., Avery, G. B., Willey, J. D., Mead, R. N., and Kieber, R. J.: Temporal variations in rainwater methanol, Atmos. Chem. Phys., 14, 10509-10516, https://doi.org/10.5194/acp-14-10509-2014, 2014.

Gómez-Pereira, P. R., Hartmann, M., Grob, C., Tarran, G. A., Martin, A. P., Fuchs, B. M., Scanlan, D. J., and Zubkov, M. V.: Comparable light stimulation of organic nutrient uptake by SAR11 and Prochlorococcus in the North Atlantic subtropical gyre, ISME J., 7, 603-614, https://doi.org/10.1038/ismej.2012.126, 2013.

Grob, C., Taubert, M., Howat, A. M., Burns, O. J., Dixon, J. L., Richnow, H. H., Jehmlich, N., Bergen, M., Chen, Y., and Murrell J. C.: Combining metagenomics with metaproteomics and stable isotope probing reveals metabolic pathways used by a naturally occuring marine methylotroph, Environ. Microbiol., 17, 40074018, https://doi.org/10.1111/1462-2920.12935, 2015.

Halsey, K. H., Carter, A. E., and Giovannoni, S. J.: Synergistic metabolism of a broad range of $\mathrm{C} 1$ compounds in the marine methylotrophic bacterium HTCC2181, Environ. Microbiol., 14, 630-640, https://doi.org/10.1111/j.1462-2920.2011.02605.x, 2012.

Halsey, K. H., Giovannoni, S. J., Graus, M., Zhao, Y., Landry, Z., Thrash, J. C., Vergin, K. L., and de Gouw, J.: Biological cycling of volatile organic carbon by phytoplankton and bacterioplankton, Limnol. Oceanogr., 62, 2650-2661, https://doi.org/10.1002/lno.10596, 2017.

Heikes, B. G., Chang, W., Pilson, M. E., Swift, E., Singh, H. B., Guenther, A., Jacob, D. J., Field, B. D., Fall, R., Riemer, D., and Brand, L.: Atmospheric methanol budget and ocean implication, Global Biogeochem. Cy., 16, Pages 80-1-80-13, https://doi.org/10.1029/2002GB001895, 2002.

Heywood, J. L., Zubkov, M. V., Tarran, G. A., Fuchs, B. M., and Holligan, P. M.: Prokaryoplankton standing stocks in oligotrophic gyre and equatorial provinces of the Atlantic Ocean: evaluation of inter-annual variability, Deep-Sea Res. Pt. II, 53, 1530-1547, https://doi.org/10.1016/j.dsr2.2006.05.005, 2006.
Kolb, S.: Aerobic methanol-oxidising bacteria in soil, FEMS Microbiol. Lett., 300, 1-10, https://doi.org/10.1111/j.15746968.2009.01681.x, 2009.

Malmstrom, R. R., Kiene, R. P., Cottrell, M. T., and Kirchman, D. L.: Contribution of SAR11 bacteria to dissolved dimethylsulfoniopropionate and amino acid uptake in the North Atlantic Ocean, Appl. Environ. Microb., 70, 4129-4135, 2004.

Mary, I., Heywood, J. L., Fuchs, B. M., Amann, R., Tarran, G. A, Burkill, P. H., and Zubkov, M. V.: SAR11 dominance among metabolically active low nucleic acid bacterioplankton in surface waters along an Atlantic meridional transect, Aquat. Microb. Ecol., 45, 107-113, https://doi.org/10.3354/ame045107, 2006a.

Mary, I., Cummings, D. G., Biegala, I. C., Burkill, P. H., Archer, S. D., and Zubkov, M. V.: Seasonal dynamics of bacterioplankton community structure at a coastal station in the western English Channel, Aquat. Microb. Ecol., 42, 119-126, https://doi.org/10.3354/ame042119, 2006b.

McDonald, I. R. and Murrell, J. C.: The methanol dehydrogenase structual gene mxaF and its use as a functional gene probe for methanotrophs and methylotrophs, Appl. Environ. Microbiol., 63, 3218-3224, 1997.

Mincer, T. J. and Aicher, A. C.: Methanol production by a broad phylogenetic array of marine phytolankton, Plos One, 11, e0150820, https://doi.org/10.1371/journal.pone.0150820, 2016.

Muyzer, G., De Waal, E. C., and Uitierlinden, A. G.: Profiling of complex microbial populations by Denaturing Gradient Gel Electrophoresis analysis of Polymerase Chain Reactionamplified genes coding for 16S rRNA, Appl. Environ. Microbiol., 59, 695-700, 1993.

Muyzer, G., Brinkhoff, T., Nubel, U., Santegoeds, C., Schäfer, H., and Waver, C.: Denaturing gradient gel electrophoresis (DGGE) in microbial ecology, in: Molecular Microbial Ecology Manual, Kluwer Academic Publishers, Dordrecht, the Netherlands, 1-27, 1998.

Nagata, T.: Organic matter-bacteria interactions in seawater, in: Microbial Ecology of the Oceans, John Wiley and Sons, NJ, USA, 207-241, 2008.

Neufeld, J. D., Schafer, H., Cox, M. J., Boden, R., McDonald, I. R., and Murrell, J. C.: Stable-isotope probing implicates Methylophaga spp and novel Gammaproteobacteria in marine methanol and methylamine metabolism, ISME J., 1, 480-491, https://doi.org/10.1038/ismej.2007.65, 2007.

Neufeld, J. D., Chen Y., Dumont, M. G., and Murrell, J. C.: Marine methylotrophs revealed by stable-isotope probing, multiple displacement amplification and metagenomics, Environ. Microbiol., 10, 1526-1535, https://doi.org/10.1111/j.14622920.2008.01568.x, 2008.

Nightingale, P. D.: Low molecular weight halocarbons in seawater, $\mathrm{PhD}$ thesis, University of East Anglia, Norwich, UK, 297 pp., 1991.

Ogawa, H. and Tanoue, E.: Dissolved organic matter in oceanic waters, J. Oceanogr., 59, 129-147, 2003.

Sargeant, S. L.: Microbial utilisation of methanol in seawater, available at: http://webcat.warwick.ac.uk/record=b2724358 S1 (last access: 21 August 2018), 2013.

Sargeant, S. L., Murrell, J. C., Nightingale, P. D., and Dixon J. L.: Seasonal variability in microbial methanol utilisation in coastal waters of the western English Channel, Mar. Ecol. Prog. Ser., 550, 53-64, 2016. 
Sieburth, J. M. and Keller, M. D.: Methylaminotrophic bacteria in xenic nanoalgal cultures: Incidence, significance, and role of methylated algal osmoprotectants, Biol. Oceanogr., 6, 383-395, 1989.

Smith, D. C. and Azam, F.: A simple, economical method for measuring bacterial protein synthesis rates in seawater using ${ }^{3} \mathrm{H}$ leucine, Marine Microbial Food Webs, 6, 107-114, 1992.

Sun, J., Steindler, L., Thrash, J. C., Halsey, K. H., Smith, D. P., Carter, A. E., Landry, Z. C., and Giovannoni, S. J.: One carbon metabolism in SAR11 pelagic marine bacteria, Plos One, 6, e23973, https://doi.org/10.1371/journal.pone.0023973, 2011.

Taubert, M., Grob, C., Howat, A. M., Burns, O. J., Dixon, J. L., Chen, Y., and Murrell, J. C.: xoxF encoding an alternative methanol dehydrogenase is widespread in coastal marine environments, Environ. Microbiol., 17, 3937-3948, https://doi.org/10.1111/1462-2920.12896, 2015.
Williams, J., Holzinger, R., Gros, V., Xu, X., Atlas, E., and Wallace, D. W. R.: Measurements of organic species in air and seawater from the tropical Atlantic, Geophys. Res. Lett., 31, L23S06, https://doi.org/10.1029/2004GL020012, 2004.

Wilson, S. M., Gleisten, M. P., and Donohue, T. J.: Identification of proteins involved in formaldehyde metabolism by Rhodobacter sphaeroides, Microbiology, 154, 296-305, https://doi.org/10.1099/mic.0.2007/011346-0, 2008.

Yang, M., Nightingale, P. D., Beale, R., Liss, P. S., Blomquist, B., and Fairall, C.: Atmospheric deposition of methanol over the Atlantic Ocean, P. Natl. Acad. Sci. USA, 110, 20034-20039, https://doi.org/10.1073/pnas.1317840110, 2013.

Yang, M., Beale, R., Liss, P., Johnson, M., Blomquist, B., and Nightingale, P.: Air-sea fluxes of oxygenated volatile organic compounds across the Atlantic Ocean, Atmos. Chem. Phys., 14, 7499-7517, https://doi.org/10.5194/acp-14-7499-2014, 2014. 